\title{
MITHRAS REDISCOVERED II. FURTHER NOTES ON CIMRM 1938 AND 1986
}

\begin{abstract}
Recently, an important Mithraic relief was rediscovered and republished by the author of these lines in collaboration with George Bounegru and Victor Sava. The relief, known in the literature as CIMRM 1938 was for a long time considered a „disappeared” monument, the only laconic description being that of Marteen J. Vermaseren from his monumental corpus. Due to the recently rediscovered photographs of the relief and the detailed analysis of the correspondence between Béla Cserni and Franz Cumont, the CIMRM 1938 is now became available for further research. In this article, I will add some further historiographic and iconographic notes on one of the biggest Mithraic reliefs found in Dacia, solving also another mysterious piece in Vermaseren's catalogue, the CIMRM 1986. The article is also the first publication of Béla Cserni's photograph about the relief.

Keywords: Mithras; Apulum; Roman religion; CIMRM 1938; CIMRM 1986
\end{abstract}

$\mathbf{T}$ he relief found on the territory of Colonia Aurelia Apulensis (probably in the North-Western part of the city) was in the Lapidarium of the first Archaeological Museum of Alba Iulia, Romania around 50 years, from 1905 till the beginning of the 1950's (Pl. I) ${ }^{1}$. During this period, the monumental relief was never published officially, only photographed twice by Béla Cserni and described by him in the letters sent to Franz Cumont ${ }^{2}$.

The Hungarian scholar attached a photograph to the letter sent to Cumont on 21 November $1912^{3}$. The photo was unknown until now, and recently found in the Franz V. Cumont Archive in Rome by Daniela Bonanno (fig. 2.) ${ }^{4}$. It is the first photograph of the relief ever made, signed with the signature of Béla Cserni himself ${ }^{5}$. On the picture, Cserni mentioned also the provenience of the relief (Colonia Apulensis) and confirmed that in 1912 the relief was in the custody of the local museum of Alba Iulia. Important to notice, that in his picture the face of Mithras seems to be better preserved as it is today, reflecting a very unusual and highly realistic smile, noticed by Cserni also in his letter. His face is the only one that is not battered, that of Sol, Luna and the torchbearers are missing completely ${ }^{6}$. As far as we know,

1 SZABÓ/BOUNEGRU/SAVA 2014.

2 On the rich correspondence and archive of Cumont, see: BONNET 1998, BONNET 2013. A photo of the Lapidarium from the first museum in Alba Iulia was published in the first article: SZABÓ/BOUNEGRU/SAVA 2014, 150, fig. 1.

3 CP 236 (AB I/5). The letter, as a part of the Franz. V. Cumont Archive is digitized and can be consulted online.

4 Inventory number: 3367, Box XXVI 5. The photo is in the custody of the Academia Belgica in Rome. It's publication here was accepted by prof. dr. Wouter Bracke, director of the institution.

5 The rediscovery of Cserni's correspondence opened a new chapter also in the research of the intellectual heritage of the great scholar.

6 If the surface of the relief was destroyed and battered in modern times, preparing the monument for his new purpose as a bench in front of a house, suggest an interesting, probably superstitious explanation, why Mithras' face was preserved completely.

\section{Csaba Szabó}

University of Pécs

szabo.csaba.pte@gmail.com

DOI: $10.14795 /$ j.v2i2.111

ISSN $2360-266 \mathrm{X}$

ISSN-L 2360 - 266X 


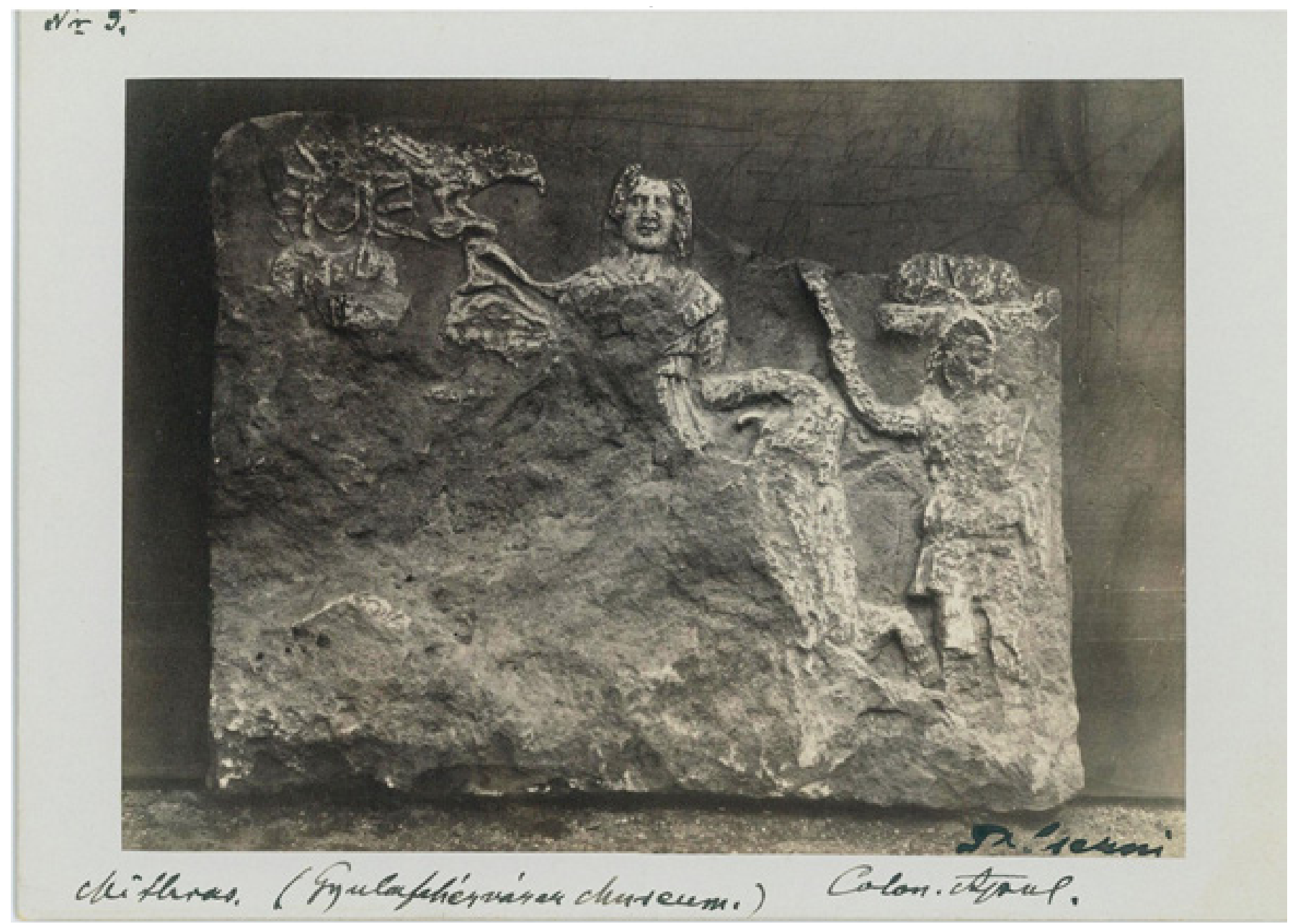

Fig. 1. The original photo of Béla Cserni about the relief. With the kind permission of the prof. Dr. Wouter Bracke and Dr. Pamela Anastasio, Academia Belgica, Roma (Franz V. Cumont Archive, inventory number: 3367, Box XXVI 5.).

the picture was never published by Cumont and remained unknown by the later research, inclusive by M. Vermaseren, who does not mention the photo in his corpus.

There was probably also an inventory description of the relief, which served as source for Vermaseren in the end of the 1950's when he visited Romania. The relief was than already in the Museum of Arad. During his visit, he collected also a rich Hungarian literature of the monuments, some of them being translated by the French Orientalist, Henri Boissin ${ }^{7}$ others were probably served by Constantin Daicoviciu, fluent in Hungarian too ${ }^{8}$. Many of the monuments and their description are based exclusively on the Hungarian literature. One of these pieces is the CIMRM $1986^{9}$. Vermaseren cites the article of Árpád Buday, preeminent member of the so-called Béla Pósta archaeological school of Transylvania ${ }^{10}$, specialist in Latin epigraphy. The Dutch scholar however cites wrongly the pagination (instead of 19, he wrote 39). Having no further information about the CIMRM 1938 and 1986, he considered as disappeared monuments. The later research simply ignored or copied his

\footnotetext{
7 SZABÓ 2014a.

8 GOMAN 2010.

9 VERMASEREN 1960, 289: „Buday in Dolgozatok VI 1930, 39 f (sic!) mentions a small Mithras relief from Apulum, which has not yet been published. On a design (Buday fig. 4.) the bust of Sol in radiate crown is visible. One ray darts out towards Mithras".
}

10 VINCZE 2014. statement ${ }^{11}$.

Buday's article ${ }^{12}$ was his third contribution on the problem of the Thracian rider, introducing the first time in the local historiography the topic of the Horsemen cults ${ }^{13}$. In this extremely interesting, however today not acceptable cogitation, Buday presents the Dieburg relief as an analogy for the syncretism and interaction between the Mithraic cult and the riders' cults in the Danubian provinces ${ }^{14}$. However his arguments on Phaeton - Mithras is not accurate ${ }^{15}$, he used numerous analogies for presenting his theory, that the association of Phaeton - Mithras appears also in the iconography of Sol with radiate crown, pointing towards Mithras $^{16}$. Two of his examples are from Apulum: one is a famous, anepigraphic relief (CIMRM 1973) where a radius of Sol not only that darts towards Mithras, but overarch

11 The CIMRM 1986 was continuously cited by numerous catalogues as a missing relief, none of the authors publishing also Buday's drawing: SICOE 2014, 162, nr. 46.

12 BUDAY 1930.

13 See also: BRRD I, 78-80.

14 The subchapter on the Dieburg relief is an answer for Behn's monograph on the finds: BEHN 1928. On the Dieburg relief, and about Mithras, as rider see: CIMRM 1247, MERKELBACH 1984, 111. On Phaeton and the symbolism of the Dieburg relief: GORDON 1975, 240, MATIJEVIC/WIEGELS 2003, 44-49. 15 He cites numerous times the article of Wilhelm Roscher from his monumental lexicon: ROSCHER 1902, 3050. Than a relatively new edition, it was very popular in Romania and Hungary too. Unfortunately, Buday does not mention in his article the extremely important analysis of Snyder on Phaeton-Mithras: SNYDER 1927.

16 BUDAY 1930, 16-17. 


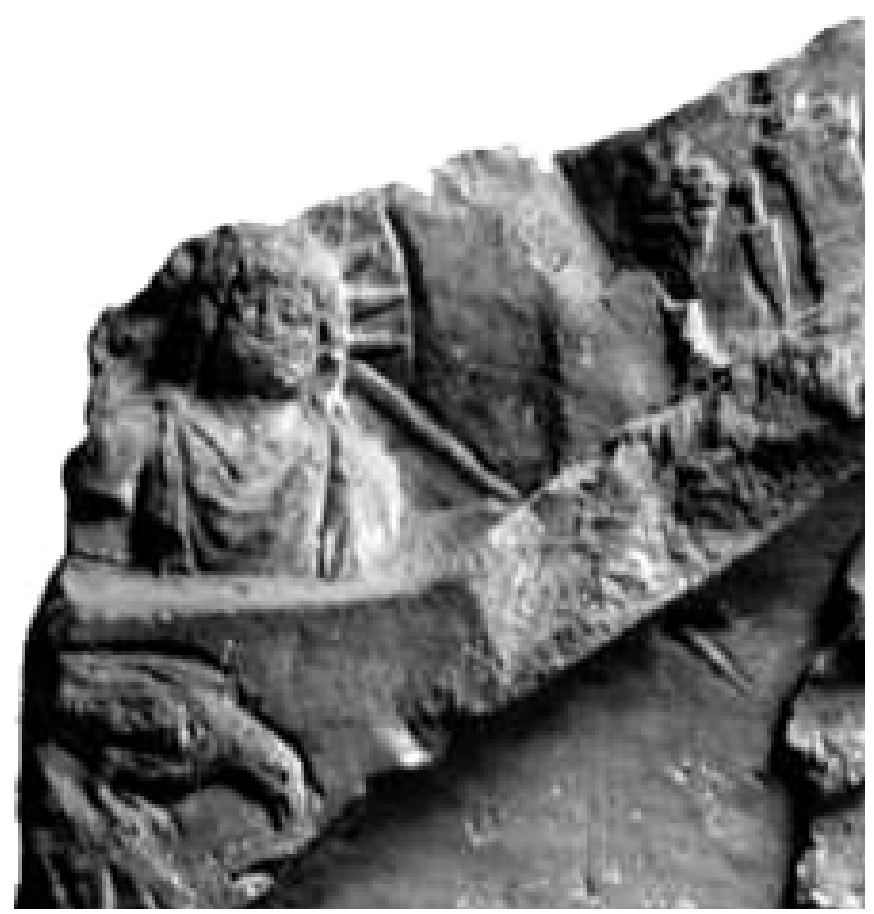

Fig. 2. The drawing of CIMRM 1938 from BUDAY 1930, 19. fig. 4.

the line of the spelaeum ${ }^{17}$ (fig. 2.), and the other one is an unpublished, "smaller" relief. The description of the objects is very laconic, it seems obvious, that Buday had as source only the published drawing (fig. 3.) and never saw the relief itself: " about the second, smaller and - as far as I know - unpublished monument I have only this drawing. It can be concluded, that one of the radius of the crown on the head of the solar divinity is longer than the others, and this one is pointing towards the bull killer"18. The drawing published about the left corner of the

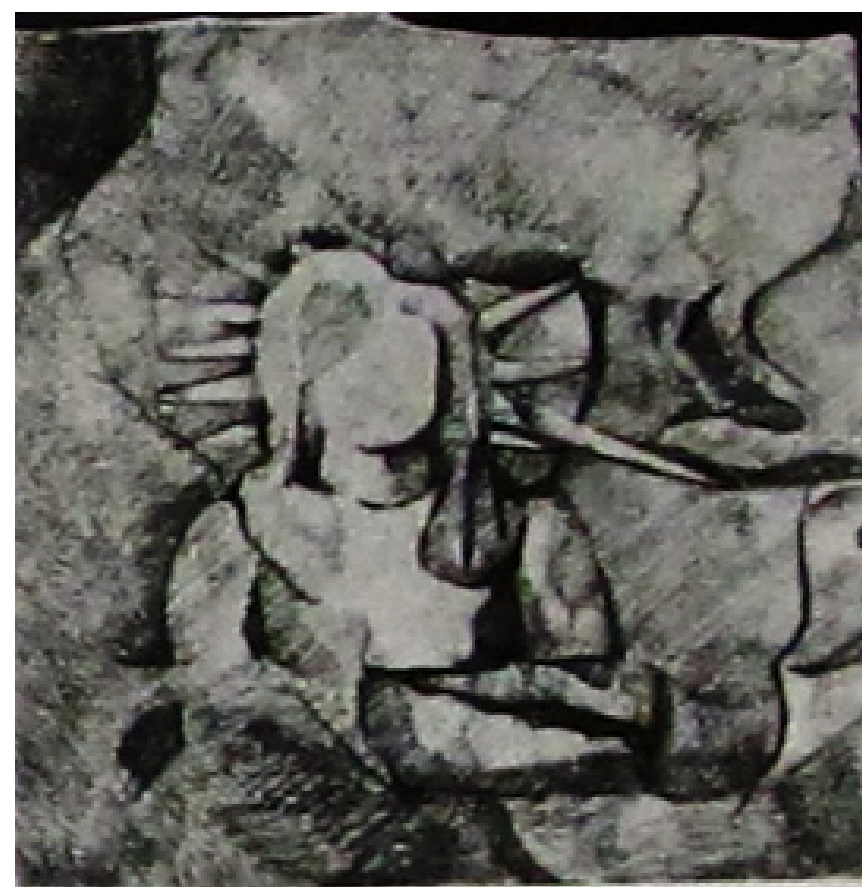

Fig. 3. The representation of Sol and it's radius on CIMRM 1973

relief is without doubt, represents the same relief mentioned and photographed by Béla Cserni and rediscovered recently 17 Idem, 17-18, fig. 3-3a.

18 Idem, 18. The drawing is on the next page of the article. in the Museum of Arad. Both on the drawing of Buday and the recently found picture of Cserni is clearly visible the long and very elegant hair of Sol and its vestment too.

Putting together all the recently found information, the contribution of Árpád Buday helped us to identify a new reference of the CIMRM 1938 and to solve the "mystery" of CIMRM 1986 - which practically never existed, being identical with the rediscovered relief of CIMRM 1938.

\section{THE RADIUS OF SOL: SYMBOLISM AND}

\section{ICONOGRAPHY}

However the argumentation of Buday regarding the relationship between the horsemen cult and Mithras is not always accurate and his Phaeton - Mithras interpretation is merely just a repetition of the Cumontian ideas, he identify two important aspects: the religious syncretism manifested in local iconographic features and the rarity of the representation of the solar radius crown in the Mithraic iconography. Beside the two mentioned reliefs from Apulum, he gives also analogies from Italy (CIMRM 366, 670) citing the corpus of Cumont and points out the importance of the number and direction of the rays in the representations.

As we already pointed out, the representation of the solar radius - crown appears very rare in the Mithraic iconography of Dacia $^{19}$ however, there are numerous examples in the Empire (CIMRM 30, 42.12, 103, 148, 172, $321,334,350,354,357,366,368,390,435,437,458,546$, 588, 597, 641, 670, 692, 759, 798, 90c, 847, 1137, 1201, $1314,1400,1579,1591,1683,1806,1893,1907,1910,2196$, $2237,2247,2255,2306)$. Sol usually appears with seven, or more rare with twelve rays on his crown. Sometimes his crown is represented in form of a nimbus as in our case too ${ }^{20}$. Although, the representation of Sol with a radius-crown is extremely wide-spread in the Empire (especially in Italy), it appears very rare in Dacia ${ }^{21}$. This aspects could be interpreted also as a specificity of the local workshop - system, which must be monopolized by some great urban communities, such as Ulpia Traiana Sarmizegetusa ("the Sarmizegetusa workshop") and probably Apulum ${ }^{22}$. The representation of the radius pointing towards Mithras is much rarer (Pl. II). ${ }^{23}$ As Buday already pointed out, all the examples known - with the exception of the two reliefs from Apulum - are came from Italy. This could indicate a direct link between the Mithraic communities of Apulum and Italy. Another iconographic feature that indicate this link is the representation of Cautes holding the bucranium, attested in some early forms only in Italy, than evolved into a particular iconography in Apulum and a single example in Boppard (Bodobrica) ${ }^{24}$. This obvious link between the Mithraic communities from Italy and Dacia could be formed due to the customs system (Publicum Portorium Illyrici) which itinerary can be reconstructed on the Rome - Aquileia - Poetovio - Apulum road ${ }^{25}$.

19 SZABÓ/BOUNEGRU/SAVA 2014, SICOE 2014, nr. 39, 102, 108, 109. 20 On the various aspects of the iconography of Sol-Helios: HIJMANS 2009. 21 It appears rare also in the Pannonian material. However, there are more numerous analogies. A possible answer for the lack of the rays could be their fragile nature, which are hardly observable on some deteriorated reliefs. 22 SICOE 2014, 59-70.

23 CIMRM 172, 350, 366, 597, 641, 670; VERMASEREN 1982, plate III, IV and XIV.

24 SZABÓ 2015a.

25 About the possible links with the communities from Rome, see: TÓTH 
This rare iconography was interpreted in numerous ways from Cumont onward: the Sun with radius crown, pointing towards Mithras with a ray or watching on the bull killer was considered for a long time a symbol of the divine messenger (corax - kerux) of Helios - Apollo and a part of a dogmatic narrative ${ }^{26}$. This was contested later by numerous scholars $^{27}$, however the real message of this iconography wasn't solved by the "new ways" and methodology of Roger Beck's "star talk"28. The standard presence of the Sol Mithras iconography on reliefs - especially on central reliefs, as our case is - suggest, however that it must be certainly an astronomic message and a historical - mythological narrative too, where the syncretic fusion of Sol - Mithras (Sol Invictus Mithras) was considered a reality ${ }^{29}$. However, the representation was influenced by the local trends, workshops, worshippers and economic realities. In most of the cases, Mithras is looking towards Sol, which is pointing to him or looking on the bull-killer, however, there are some cases - also the CIMRM 1938 - where Mithras is looking towards the audience, the worshippers, emphasizing the importance and emotional, performant effect of what a central relief, a signum mean to be ${ }^{30}$. Representing Mithras in front of the worshippers with a direct and very powerful contact with Sol, the relief was meant to emphasize a certain aspect of the Mithras - narrative and star talk. In fact, Sol pointing towards Mithras reflect not only the clear solar fusion and syncretism of Sol Invictus Mithras, but emphasize that iconographic tradition and also, innovation, which exist in the Greco - Roman world when they "invent" Mithras ${ }^{31}$. Divinities pointing towards the viewer, such as Mithras reflect in this case is a common iconographic expression of divine contact, often represented in statues or described in literary texts.

A central relief, as the CIMRM 1938, was ordered by a wealthy member or the whole Mithraic community and installed in the mithraeum, which became a sacred geography, a "star talk", where every piece, object had a significance and a religious purpose. Not only the spatial arrangement, but also the chromatic, light and soundscape of a sanctuary played an important role in recreating the mythical spelaeum ${ }^{32}$.

\section{CONCLUSION}

The recently found historiographic sources helped us to reinterpret the CIMRM 1938, rediscovered in the deposit of the Museum of Arad and to clarify the mysterious CIMRM 1986, which is identical with the first mentioned relief. Analyzing the relief and its iconographic features proved also the direct link between the Mithraic communities from Italy and Apulum, known already from economic and commercial routes. Rediscovering one of the biggest Mithraic relief of Dacia after 60 years of disappearance in a deposit of a

1992, 153 - 160, SZABÓ 2015b.

26 VERMASEREN 1982, 66-67.

27 GORDON 1975, BECK 2006, 18-23, GORDON 2013a, 237-242.

28 CHALUPA 2012.

29 On the syncretism of Sol and Mithras, see: HIJMANS 1996, HIJMANS 2009, GARCIA 2010.

30 GORDON 2013b, 211-218.

31 On a new theory of Mithraic iconography, see: FARAONE 2013.

32 There are no traces of painting on the relief, however it is possible that as many of the central reliefs, it was colorful. museum based only on archive sources and literature ${ }^{33}$ shows the great possibilities and new perspectives of research. They should not focus only on the systematic publication of the new excavations and researches but also the revision of the old repertories and the reorganization of the museum storerooms, known many times as "labyrinths of knowledge", still hosting numerous unpublished artifacts. Publishing the CIMRM 1938 was also a first step of a comprehensive work to establish a Supplementum for CIMRM of Dacia ${ }^{34}$.

\section{ACKNOWLEDGEMENTS}

I would like to express my greatest gratitude to Dr. Daniela Bonanno and Dr. Corinne Bonnet for their kindly help, consulting the Archive of Franz V. Cumont in Rome and serving valuable information about the correspondence of the great scholar. I thank to Dr. Pamela Anastasio, curator of the F.V. Cumont Archive and prof. Dr. Wouter Bracke, director of the Academia Belgica in Rome for their kindly permission to publish the original photo of Béla Cserni, now in the custody of the Academia Belgica, Franz V. Cumont Archive.

\section{ABBREVIATIONS}

BRRD - Boda, I./Szabó Cs., The bibliography of Roman religion in Dacia (Cluj - Napoca, 2014)

CIMRM - Vermaseren, M., Corpus Inscriptionum Monumentorum Religionis Mithriacae I -II (The Haguae, 1960)

\section{REFERENCES}

\section{BONNET 1998}

Bonnet, C., La formation de Franz Cumont d'aprés sa BONNET 2013 correspondance (1885 - 1892), Kernos 11, 245-264.

Bonnet, C., Die „orientalischen Kulte” im Werk des Franz Cumont, In: Hattler, C. (ed.), Imperium der Götter. Isis Mithras - Christus. Kulte und religionen im Römischen Reich (Karlsruhe: Badische Landesmuseum), 66 - 73.

\section{BONNET/KRINGS 2008}

Bonnet, C. / Krings, V. (eds.), S'écrire et écrire sur l'Antiquité. L'apport de correspondences a l'histoire des travaux scientifiques BECK 2006 (Grenoble: Éditions Gérome Millon).

Beck, R., The religion of the Mithras Cult in the Roman Empire: Mysteries of the unconquered Sun (Oxford: Oxford University Press).

BUDAY 1930

Buday Á., Újabb adatok rómaikori lovasisten ábrázolásainak problémáihoz, Dolgozatok az Erdélyi Múzeum Érem és Régiségtárából 6/1-2, 1 - 25(Szeged)

\section{CHALUPA 2012}

Chalupa, A., Paradigm lost, paradigm found? Larger theoretical assumptions behind Rober Beck's The Religion of the Mithras cult in the Roman Empire, Pantheon. Journal for the study of religions 7/1, 5-17.

\section{FARAONE 2013}

33 On the importance of the correspondences and archive material in the research of Roman religious studies, see: BONNET/KRINGS 2008.

34 On the new perspectives and new research areas in the study of Roman religion of Dacia see: NEMETI/MARCU 2014, 15-16, SZABÓ 2014b, 200201. 
Faraone, Ch., The amuletic design of the Mithraic bull wounding scene, Journal of Roman studies 103, 1-21.

GARCIA 2010

Garcia, J. R., La problematique de Sol Invictus. Le cas de la Dacie Romaine, Numen 57, 1-36.

\section{GOMAN 2010}

Goman, M., Activitatea didactică și științifică a lui Constantin Daicoviciu. Unpublished Ph.D. thesis (Oradea. Universitatea din Oradea)

GORDON 1975

Gordon, R., Franz Cumont and the doctrines of Mithraism, In: Hinnells, J. (ed.), Mithraic studies. Proceedings of the First International Congress of Mithraic Studies (Manchester: Manchester University Press), 215-248.

GORDON 2013a

Gordon, R., Von Cumont bis Clauss. Ein Jahrhundert Mithras - Forschung, In: Hattler, C. (ed.), Imperium der Götter. Isis - Mithras - Christus. Kulte und religionen im Römischen Reich (Karlsruhe: Badische Landesmuseum), 237-242.

GORDON 2013b

Gordon, R., „Glücklich ist dieser Ort...”. Mithras Heiligtümer und Kultgeschehen, In: Hattler, C. (ed.), Imperium der Götter. Isis - Mithras - Christus. Kulte und religionen im Römischen Reich (Karlsruhe: Badische Landesmuseum), 211-218.

HIJMANS 1996

Hijmans, S., The Sun which Did not Rise in the East. The Cult of Sol Invictus in the Light of Non-Literary Evidence, BABESCH - Annual Papers on Mediterranean Archaeology 71, $115-150$.

HIJMANS 2009

Hijmans, S., The sun in the art and religions of Rome (Groningen: University Library Groningen).

\section{MERKELBACH 1984}

Merkelbach, R., Mithras (Königstein: Hain).

MATIJEVIC/WIEGELS 2003

Matijevic, K. /Wiegels, R., Zeugen der Vergangheit. Inschriften und Weihedenkmäler aus dem römischen Dieburg (Dieburg)

NEMETI/MARCU 2014

Nemeti, S./ Marcu, F., The historiography of religions in Roman Dacia. A brief account. In: Boda, I./Szabó, C., (eds.), The Bibliography of Roman Religion in Dacia (Cluj-Napoca:
Mega Publishing House), 9-20.

ROSCHER 1902

Roscher, W. (ed.), Ausführliche Lexikon der griechischen und römischen Mythologie. Band III.1. (Leipzig: Teubner Verlag).

\section{SICOE 2014}

Sicoe, G., Mithräischen Steindenkmäler aus Dakien (Cluj Napoca: Mega Verlag).

\section{SNYDER 1927}

Snyder, G., De symbolica Phaethonti fabulae interpretatione apud Romanos, Mnemosyne 55, 1927, 401-409.

SZABÓ/BOUNEGRU/SAVA 2014

Szabó Cs. /Bounegru, G. /Sava, V., Mithras rediscovered. Notes on CIMRM 1938, Ziridava. Studia Archaeologica 28, 149-156.

SZABÓ 2014a.

Szabó Cs., Notes ont he Mithraic small finds from Sarmizegetusa, Ziridava. Studia Archaeologica 28, 135-148.

SZABÓ 2014b

Szabó Cs., Roman religious studies in Romania. Historiography and new perspectives, Ephemeris Napocensis $24,195-204$.

SZABÓ 2015a

Szabó Cs., Notes on a new Cautes statue from Apulum, Archäologische Korrespondenzblatt 2 (forthcoming).

SZABO 2015b

Szabó Cs., The cult of Mithras in Apulum. Communities and individuals, In: Zerbini, L. (ed.), Atti el convegnio "Roman Religion in the Danubian provinces". Ferrara, 18-22 November 2013. (forthcoming).

\section{TÓTH 1992}

Tóth I., A Dacian „Apostole” of the cult of Mithras?, Specimina Nova 8, 153-160.

\section{VERMASEREN 1960}

Vermaseren, M., Introduction, In: CIMRM.

VERMASEREN 1982

Vermaseren, M., Mithriaca III. The mithareum at Marino (Leiden: Brill).

\section{VINCZE 2014}

Vincze Z., A kolozsvári régészeti iskola a Pósta Béla korban (1899-1919), (Cluj-Napoca: Erdélyi Múzeum Egyesület). 


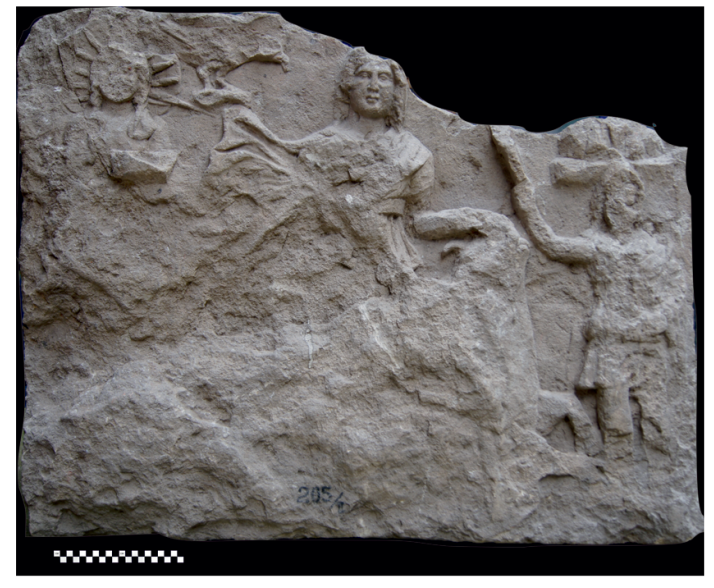

a

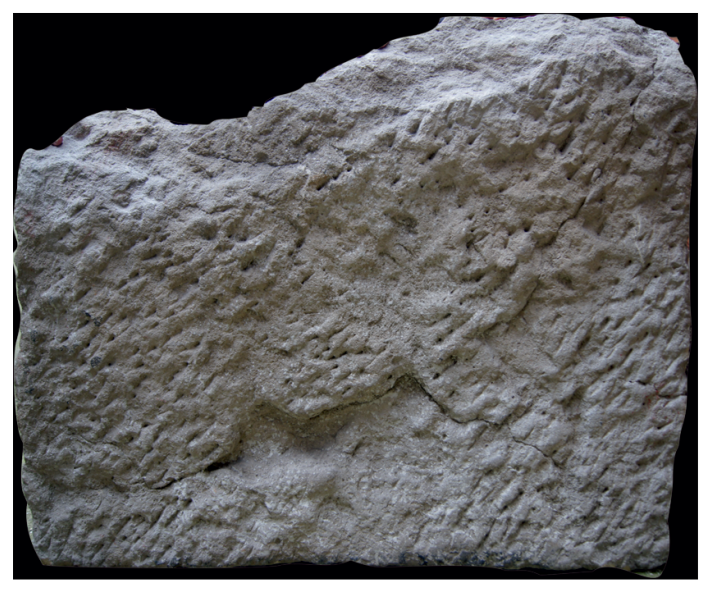

b

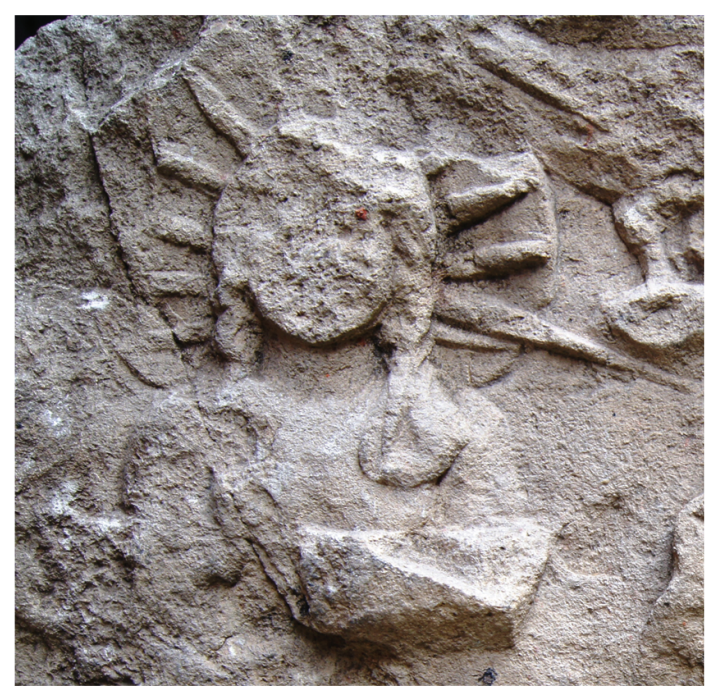

C

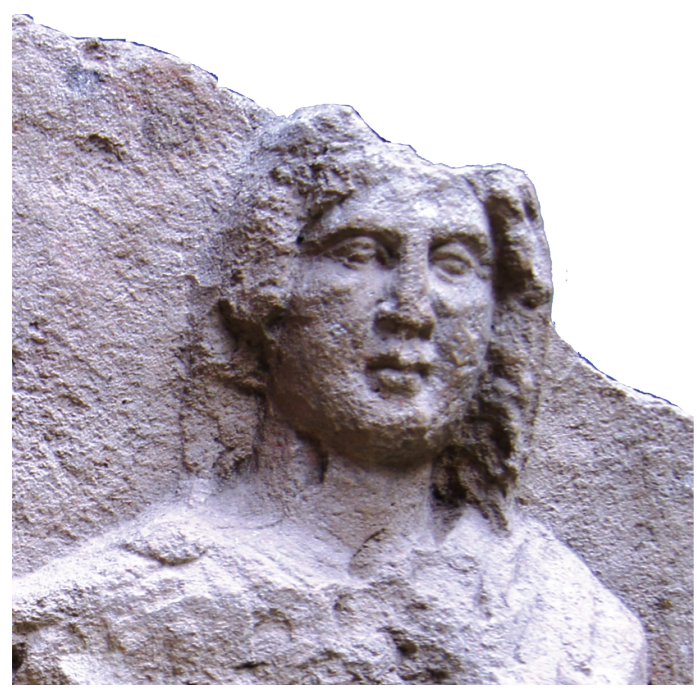

d

Pl. I. a. Front side of the CIMRM 1938 recently rediscovered in the Museum of Arad. Photo by Victor Sava; b. Rear side of the CIMRM 1938 recently rediscovered in the Museum of Arad. Photo by Victor Sava; c. Detail, bust of Sol; d. Detail, Mithras 


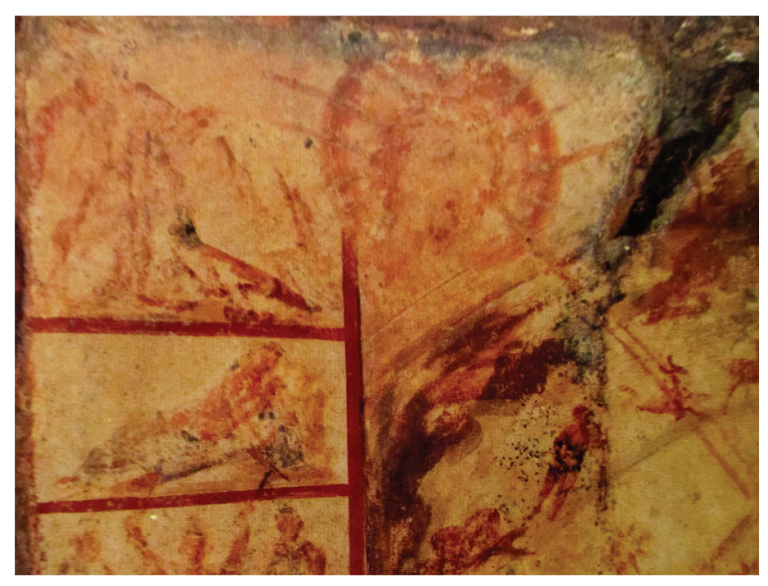

a

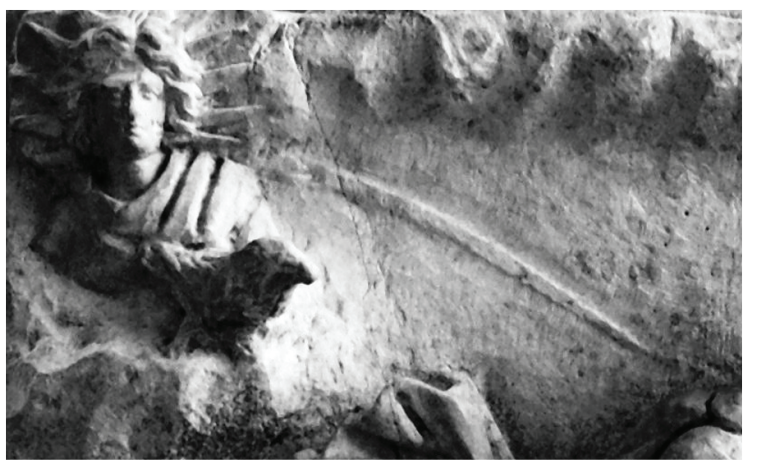

C

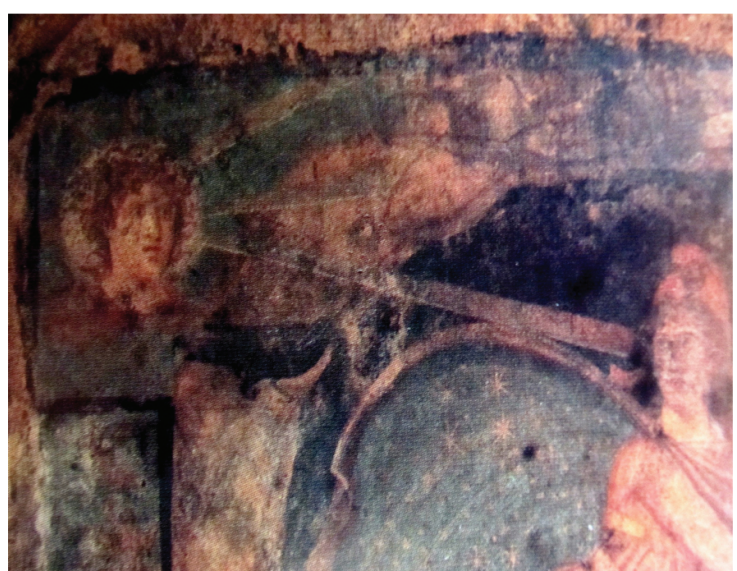

b

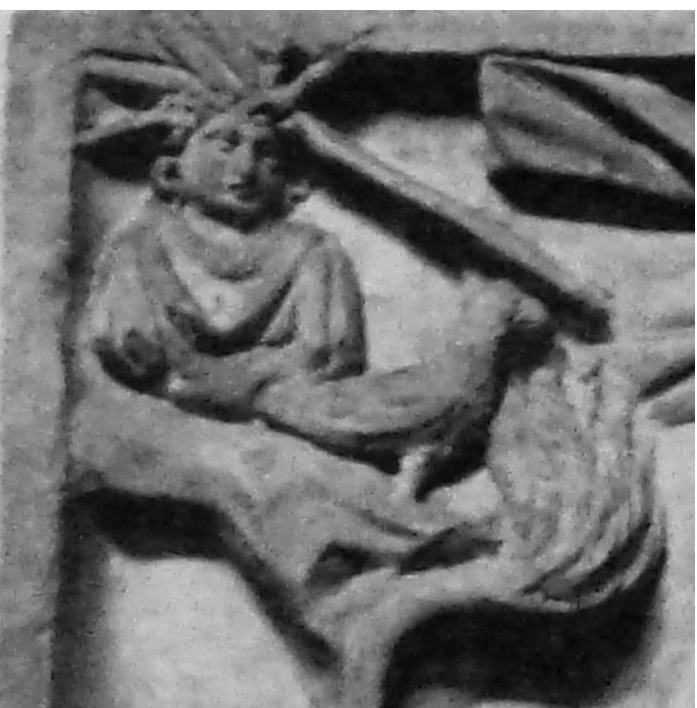

P1. II. Representation of Sol with radius, pointing toward Mithras on different analogies from Italy: a. Barberini mithraeum (after VERMASEREN 1982); b. Marino mithraeum (after VERMASEREN 1982); c. CIMRM 641; d. CIMRM 641. 